\title{
PROSES PENDIDIKAN/PEMBELAJARAN
}

\author{
Husnul Amin \\ Sekolah Tinggi Ilmu Tarbiyah Raudhatul Ulum Sakatiga \\ Email: amin_husnul@yahoo.co.id
}

\begin{abstract}
Abstrak
Proses pendidikan dalam literatur ilmu pendidikan, khususnya ilmu pengajaran, direduksi menjadi proses pengajaran atau proses pembelajaran, sebab mungkin proses pengajaran/pembelajaran lebih jelas, lebih tegas, objektif, bahkan universal, sedangkan proses pendidikan selain mengajar lebih subjektif, kurang jelas, kurang tegas, lebih bersifat seni daripada sebagai sains.

Proses pembelajaran (Intructional) yang sering disingkat menjadi PBM (Proses Belajar Mengajar) adalah bagian terpenting yang bersifat aktif dari kurikulum. Kurikulum menurut Nasution meliputi 4 (empat) komponen pokok, terdiri dari (1) tujuan, (1) bahan pelajaran, (3) proses belajar mengajar, dan (4) penilaian. Dalam al-Qur'an dan hadits dapat ditemukan berbagai metode pendidikan yang sangat menyentuh perasaan, mendidik jiwa, dan membangkitkan semangat. Metode itu adalah: Metode hiwar (percakapan) Qurani dan Nabawi, Metode kisah Qurani dan Nabawi, Metode amtsal (perumpamaan) Qurani dan Nabawi, Metode keteladanan, Metode pembiasaan, Metode 'ibrah dan mau'izah, dan Metode taghrib dan tarhib.
\end{abstract}

Kata Kunci: Proses, Pendidikan

\section{Landasan Syar'i tentang Proses Pembelajaran}

1. Al-Qur'an surat Al-Baqarah ayat 282 (Depag RI,2002:71)

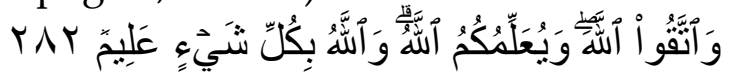

"Dan bertakwalah kepada Allah, Allah mengajarmu; dan Allah maha mengetahui segala sesuatu"

2. Al-Qur'an surat Al-Hajj ayat 78 (Depag RI,2002:523)

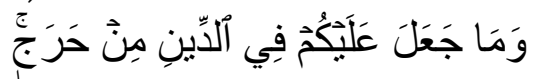

"Dan Dia sekali-sekali tidak menjadikan untuk kamu dalam agama suatu kesempitan"

\section{Dasar Hukum Proses Pembelajaran di Indonesia}

1. UUD Republik Indonesia 1945 pasal 31:

(1) Tiap-tiap warga negara berhak mendapat pengajaran

(2) Pemerintah mengusahakan dan menyelanggarakan satu sistem pengajaran nasional yang diatur dengan undang-undang. 


\section{Proses Pendidikan/Pembelajaran \\ Husnul Amin}

2. UUD Republik Indonesia Nomor 20 Tahun 2003, BAB III Pasal 4:

(1) Pendidikan diselenggarakan secara demokratis dan berkeadilan serta tidak diskriminatif dengan menjunjung tinggi hak asasi manusia, nilai keagamaan, nilai kultural, dan kemajemukan bangsa.

(2) Pendidikan diselenggarakan sebagai satu kesatuan yang sistematik dengan sistem terbuka dan multimakna.

(3) Pendidikan diselenggarakan sebagai suatu proses pembudayaan dan pemberdayaan peserta didik yang berlangsung sepanjang hayat.

(4) Pendidikan diselenggarakan dengan memberikan keteladanan, membangun kemauan, dan mengembangkan kreatifitas peserta didik dalam proses pembelajaran. (Tim Redaksi FOKUDMEDIA, 2006:6)

3. PP Republik Indonesia Nomor 19 Tahun 2005 tentang Standar nasional Pendidikan, Bab IV

\section{Pasal 19}

(1) Proses pembelajaran pada satuan pendidikan diselenggarakan secara interaktif, inspiratif, menyenangkan, memotivasi peserta didik untuk berpartisipasi aktif, serta memberikan ruang yang cukup bagi prakarsa, kretivitas, dan kemandirian sesuai dengan bakat, minat, dan perkembangan fisik serta psikologi peserta didik.

(2) Selain ketentuan sebagai mana dimaksud pada ayat (1),dalam proses pembelajaran pendidik memberikan keteladanan

(3) Setiap satuan pendidikan melakukan perencanaan proses pembelajaran, pelaksanaan proses pembelajaran, penilaian hasil pembelajaran, dan pengawasan proses pembelajaran untuk terlaksananya proses pembelajaran yang efektif dan efisien.

\section{Pasal 21}

(1) Pelaksanaan proses pembelajaran sebagai mana dimaksud dalam pasal 19 ayat (3) harus memperhatikan jumlah maksimal peserta didik perkelas dan beban mengajar maksimal per pendidik, rasio maksimal buku teks pelajaran setiap peserta didik, dan rasio maksimal juml;ah peserta didik setiap pendidik.

(2) Pelaksanaan proses pembelajaran dil;akukan dengan mengembangkan budaya membaca dan menulis. (Tim Redaksi FOKUDMEDIA, 2006:74-75)

\section{Proses Pendidikan/ Pembelajaran}

Proses pendidikan dalam literatur ilmu pendidikan, khususnya ilmu pengajaran, direduksi menjadi proses pengajaran atau proses pembelajaran, sebab mungkin proses pengajaran/pembelajaran lebih jelas, lebih tegas, objektif, bahkan universal, sedangkan 
P-ISSN : 2541-3686

proses pendidikan selain mengajar lebih subjektif, kurang jelas, kurang tegas, lebih bersifat seni daripada sebagai sains.

Proses pembelajaran (Intructional) yang sering disingkat menjadi PBM (Proses Belajar Mengajar) adalah bagian terpenting yang bersifat aktif dari kurikulum. Kurikulum menurut Nasution meliputi 4 (empat) komponen pokok, terdiri dari (1) tujuan, (1) bahan pelajaran, (3) proses belajar mengajar, dan (4) penilaian.

PBM atau pembelajaran ialah proses kegiatan komunikasi dua arah yang dirancang untuk membantu seseorang mempelajari suatu kemampuan dan/atau nilai yang baru.

Proses belajar mengajar merupakan proses interaksi edukatif antara guru yang menciptakan suasana belajar dan pelajar yang memberi respons terhadap usaha guru tersebut. (DITJEN BINBAGA ISLAM DEPAG RI, 2001:88)

Dalam proses pembelajaran, seorang pendidik dituntut untuk memilih model dan metode mengajar yang akan digunakan. Namun yang paling penting dari itu adalah merumuskan langkah-langkah pembelajaran.

\section{Model Pengajaran}

Model mengajar dapat dianggap teori mini yang bersifat mekanis dalam arti berjalan secara tetap seperti mesin, sebagai blue print yang direkayasa sedemikian rupa untuk mencapai tujuan-tujuan tertentu pengajaran.

Suatu model mengajar dapat diartikan sebagai suatu rencana atau pola yang digunakan dalam menyusun kurikulum mengatur materi pengajaran dan memberi petunujuk kepada pengajar di kelas dalam setting pengajaran dan setting lainnya. (Dahlan, 1990:21)

Model pengajaran terdiri dari:

1. Model pengajaran beracuan prosedur

2. Model pengajaran beracuan tujuan (DITJEN BINBAGA ISLAM DEPAG RI, 2001:67-70)

Menurut DeQueljoe dan A. Ghazali Dalam Buku Didaktik Umum, ada empat model pengajaran:

1. Jalan pelajaran konsentris (seluruh bahan pelajaran dijalani beberapa kali dari permulaan hingga akhir, dimulai dari yang paling mudah dan paling penting)

2. Jalan pelajaran suksesif (seluruh bahan yang dilalaui satu kali, karena pengajaran maju secara berurutan)

3. Jalan pelajaran sintesis (kegiatan belajar mengajar dimulai dari pembelajaran unsur-unsur atau bagian-bagian untuk selanjutnya membuat kesimpulan atau merumuskan keseluruhan/bertumpuk pada penalaran induktif)

4. Jalan pelajaran analisis (dimulai dari yang umum, menju yang khusu; dari keutuhan menuju bagian-bagian/prinsip yang mendasarinya ialah model deduktif. (Ahmad Tafsir, 1996:38) 


\section{Proses Pendidikan/Pembelajaran \\ Husnul Amin}

Model mengajar menurut Bruce Joyce dan Marsha Weil

1. Model Information Proccesing

2. Model Personal (sorogan), lawannya classikal (biasanya guru BP)

3. Model soccial (membentuk hidup bersama dalam perbedaan)

4. Model behavioral (tingkah laku/demontrasi)

Model Information Proccesing

1. Inquiry (belajar meniliti/latihan meneliti) Siswa diberi tugas dengan diberi kisikisi

2. Model presentasi kerangka dasar (advance organizer)

3. Model pengembangan berpikir

Keragaman Model Yang Diterapkan Diharapkan Mampu Menjangkau Banyak Sisi Kebutuhan Siswa Di Kelas. Pemahaman Diri Siswa Dapat Dicapai Melalui Model-Model personal, membina kerjasama dalam kelompok dapat dihampiri melalaui rumpun social, kemampuan memproses informasi dapat didekati dengan rumpun information proccessing, dan penguasaan keterampilan dapat dilatih melalui rumpun behavior modivication. (Dahlan, 1990:14)

\section{Metode Mengajar}

Metode ialah cara yang teratur dan terpikir baik-baik untuk mencapai maksud (dalam ilmu pengetahuan dsb); cara kerja yang bersistem untuk memudahkan pelaksanaan suatu sistem guna mencapai tujuan yang dibutuhkan. (KBBI, 1997:652) Metode mengajar ialah cara yang digunakan guru untuk menyampaikan pelajaran kepada pelajaran; cara yang dipergunakan guru dalam mengadakan hubungan dengan pelajar pada saat berlangsungnya pengajaran; alat untuk menciptakan proses belajar mengajar (DITJEN BINBAGA ISLAM DEPAG RI, 2001:88)

Metode mengajar yang baik adalah metode yang dapat menumbuhkan kegiatan belajar bagi pelajar, dan upaya guru dalam memilih metode yang baik merupakan upaya mempertinggi mutu pengajaran atau pendidikan yang menjadi tanggung jawabnya.

\section{Beberapa Metode Mengajar}

1. Ceramah

2. Tanya jawab

3. Diskusi (diskusi kelompok)

4. Demontrasi dan eksperimen

5. Tugas belajar dan resitasi

6. Kerja kelompok

7. Sosiudrama (role playing)

8. Pemecahan masalah (problem solving)

9. Sistem regu (team teaching)

10. Karyawisata (field trip)

11. Manusia sumber (resiurce person) 
P-ISSN : 2541-3686

12. Survei masyarakat

13. Simulasi

14. Studi kasus

15. Tutorial

16. Curah gagasan (brain storming)

17. Studi bebas

18. Kelompok tanpa pemimpin

19. Latihan (drill)

20. Latihan kepekaan (DITJEN BINBAGA ISLAM DEPAG RI, 2001:103-132)

Menurut Ali Ahmad Madkur, ada beberapa metode mengajar:

1. Thariqat al-Qudwat

2. Thariqat al-Ilqa' wa al-Tafa'ul (Thariqat al-Talqin)

3. Thariqat al-muhadarah wa al-munaqasyah wa al-munadharah

4. Thariqat al-qishshah

5. Tahriqat al-Tarbiyah bin al-Ahdats

6. Tahriqat Takwin al-'Adat al-Hasanat

7. Tahriqat al-matsubat wa al-Uqubat

8. Tahriqat istitsmar al-Juhd wa al-Waqt al-Faidlin

9. Tahriqat al- Munaqasyat wa al-Hiwar

10. Tahriqat hall al-Musykilat

11. Tafrid al-Ta'lim wa al-Ta'allum al-Dzati

12. Al-Tadris bi al-Fariq

13. Al-Ta'lim al-Mushaggir (Ali Ahmad Madkur, 2002:323-354)

Dalam al-Qur'an dan hadits dapat ditemukan berbagai metode pendidikan yang sangat menyentuh perasaan, mendidik jiwa, dan membangkitkan semangat. Metode itu adalah:

1. Metode hiwar (percakapan) Qurani dan Nabawi

2. Metode kisah Qurani dan Nabawi

3. Metode amtsal (perumpamaan) Qurani dan Nabawi

4. Metode keteladanan

5. Metode pembiasaan

6. Metode 'ibrah dan mau'izah

7. Metode taghrib dan tarhib (Ahmad Tafsir, 2005:135)

\section{Prinsip dan pertimbangan dalam proses pembelajaran}

Hal utama dalam proses pembelajaran adalah menentukan prosedur (langkahlangkah) pembelajaran. Keberhasilan mengajar banyak ditentukan oleh langkahlangkah yang ditempu seorang pendidik dalam proses pembelajaran dalam menetapkan langkah-langkah pembelajaran, perlu diperhatikan beberapa prinsip dan pertimbangan. Prinsip-prinsip tersebut adalah:

1. Memperhatikan kecendrungan-kecendrungan murid;

2. Memanfaatkan aktivitas individual murid; 


\section{Proses Pendidikan/Pembelajaran \\ Husnul Amin}

3. Mendidik melalui permainan atau menjadikan permainan sebagau sarana pendidikan;

4. Menerapkan prinsip kebebasan yang rasional didalam PBM tanpa membebani murid dengan perintah dan larangan yang tidak mereka butuhkan;

5. Memberi motivasi kepada para pelajar untuk berbuat, bukan untuk menekannya;

6. Mengutamakan dunia anak-anak, dalam arti memperhatikan kepentingan mereka dan mempersiapkan mereka untuk kehidupan dimasa depan;

7. Menciptakan semangat berkoperasi (bekerjasama)

8. Memberi motivasi kepada murid untuk belajar mandiri serta memiliki kepercayaan diri untuk melakukan tugas-tugas belajar dan penelitian;

9. Memanfaatkan segenap indera murid

Adapun pertimbangan-pertimbangan yang harus diperhatikan adalah:

1. Keadaan murid yang mencakup pertimbangan tentang tingkat kecerdasan, kematangan, perbedaan individu lainnya.

2. Tujuan yang hendak dicapai

3. Situasi yang mencakup hal yang umum seperti situasi kelas, situasi lingkungan

4. Alat-alat yang tersedia

5. Kemampuan pengajar, mencakup kemampuan fisik dan keahlian

6. Sifat bahan pengajaran

7. Kekuatan dan kelemahan metode, model, langkah-langkah

Langkah-langkah dalam proses pembelajaran pada umunya meliputi:

1. Appersepsi/Pre test

2. Penyampaian materi pelajaran

3. Pos test

\section{Simpulan}

1. Proses pendidikan direduksi menjadi proses pengajaran atau proses pembelajaran. Dalam proses pembelajaran, seorang pendidik dituntut untuk memilih model dan metode megajar yang akan digunakan. Namun yang paling penting dari itu adalah merumuskan langkah-langkah pembelajaran.

2. Syara', negara dan ilmu pendidikan memberikan kebebasan dalam melaksanakn (proses) pembelajaran dan cukup untuk mendorong untuk pembelajaran yang berpusat kepada murid (stundent centre).

3. Dari beberapa faktor yang menjadi pertimbangan dalam menentukan langkahlangkah pembelajaran, dalam realitanya, yang paling menentukan kemampuan guru. Oleh karena itu, peneingkatan kualitas/kompetensi guru sangat diperlukan untuk keberhasilan pendidikan pembelajaran. 
RAUDHAH Proud To Be Professionals qurnal Tarbiyakndamiyah

Volume 3 Nomor 1 Edisi Juni 2018

P-ISSN : 2541-3686

\section{DAFTAR PUSTAKA}

Dahlan (Penyuting). 1990. Model-Model Mengajar: Beberapa Alternatif Interaksi Belajar Mengajar. Bandung: Diponegoro.

Departemen Agama RI, 2002. Al-Qur'an Dan Terjemahannya Surabaya: Alhidayah.

Ditjen. Binbaga Islam Departemen Agama RI, 2001. metodologi Pendidikan Agama Islam, Jakarta : Ditjen Binbaga Islam Departemen Agama RI.

JOYCE, B. Dan WEIL, M., 2000. Models Of Teaching. Boston: Allyn And Bacon.

Madkur, Ali Ahmad, 2002. Manhaj Al-Tarbiyah Fi Al-Tashawwur Al-Islamy, Cairo : Dar Al-Fikr Al-'Araby.

Muhaimin Dan Mujib, Abdul, 1993. Pemikiran Pendidikan Islam: Kajian Filosofis Dan Kerangka Dasar Operasionalisasinya, Bandung: Trigenda Karya.

Muhibbinsyah,2003. Psikologi Pendidikan Dengan Pendekatan Baru, Bandung: Remaja Rosdakarya.

Nasution, S. 2000. Berbagai Pendekatan Dalam Proses Belajar Mengajar, Jakarta: Bumi Aksara.

Ramayulis, 1990. Metodologi Pengajaran Agama Islam, Jakarta: Kalam Mulia.

Surachmad, Winarno, 1980. Pengantar Interaksi Belajar Mengajar: Dasar Dan Teknik Metodologi Pengajaran, Bandung: Tarsito.

Tafsir, Ahmad, 2005. Ilmu Pendidikan Dalam Perspektif Islam, Bandung: Remaja Rosdakarya.

------, 1996. Metodologi Pengajaran Agama Islam, Bandung: Remaja Rosdakarya.

------, 2006. Filsafat Pendidikan Islami: Integrasi Jasmani, Rohani Dan Kalbu, Memanusiakan Manusia, Bandung: Remaja Rosdakarya.

Tim Redaksi Fokusmedia, 2006. Himpunan Peraturan Perundang-Undangan Tentang Sistem Pendidikan Nasional, Bandung: Fokusmedia.

Tim Penyusun Kamus Pusat Pembinaan Dan Pengembangan Bahasa Depdikbud, Kamus Besar Bahasa Indonesia, Jakarta: Balai Pustaka. 
Proses Pendidikan/Pembelajaran

Husnul Amin 